Indian Journal of Science and Technology

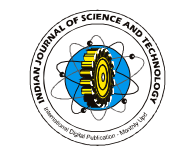

\title{
High incidence of loss of $R A R A-P M L$ chimeric gene of acute myelocytic leukemia M3 with simple or complex 15;17 translocation
}

\author{
Kimio Tanaka ${ }^{1 *}$, Takahiro Shintani ${ }^{2}$, Masako Minamihisamatsu ${ }^{3}$, Taichi Kyo ${ }^{4}$, Nanao Kamada ${ }^{5}$ \\ ${ }^{1}$ Department of Radiobiology, Institute for Environmental Sciences, Hachazawa 2-121, Takahoko, Rokkasho, \\ Kamikita, Aomori 019-3213, Japan \\ ${ }^{2}$ Department of Cancer Cytogenetics, Research Institute for Radiation Biology and Medicine, Hiroshima University, \\ Kasumi 1-2-3, Minamiki-ku, Hiroshima 734-8552, Japan \\ ${ }^{3}$ Radiation Hazards Research Group, National Institute for Radiological Sciences, Anagawa 4-9-1, Chiba 263-8555, \\ Japan \\ ${ }^{4}$ Fourth Department of Internal Medicine, Hiroshima Red Cross Hospital, Senda-machi, 1-9-6, Minami-ku, Hiroshima \\ 739-1743, Japan \\ ${ }^{5}$ Hiroshima Atomic Bomb Relief Foundation, 50-1, 3 Chome Asakita-ku, Hiroshima 739-1743, Japan \\ *kmtanaka@ies.or.jp
}

\begin{abstract}
Acute myelocytic leukemia (AML), French-American-British (FAB) classification M3 contains variable clinical disease. About $90 \%$ of the AMLM3 has specific reciprocal chromosome translocation between chromosomes 15 and 17, which resulted in PML-RARa and RARa-PML chimeric genes. We analyzed 39 AMLM3 patients who showed typical clinical M3 symptoms, with simple or complex 15;17 translocation or not, by metaphase and interphase fluorescence in situ hybridization (FISH) methods using both of PML-RAR $\alpha$ and RARa-PML chimeric probes or reverse transcriptase PCR of PML-RAR $\alpha$ chimeric gene. Thirty-one patients reported positive for $P M L-R A R \alpha$ gene while eight patients did not. Of interest, 6 of the 31 PML-RAR a positive AMLM3 patients (19.4\%) did not show RARa-PML chimeric signal, which was considered to be the cases having the deletion of the region locating $R A R \alpha-P M L$ chimeric gene on der (17) chromosome either after or at the same time of formation of simple 15;17 translocation. Out of 6, 2 patients had complex $15 ; 17$ translocation of $\mathrm{t}(3 ; 15 ; 17)$ and ins $(15 ; 17)$. Two-way translocation model might be more acceptable to show the mechanisms for formation of complex 15;17 translocation and insertion 15;17 where insertion of a region of chromosome 17 involving RARa into PML region of chromosome 15. These precise FISH analysis also revealed that AMLM3 acquired variable chromosomal instabilities such as deletion of $R A R \alpha$ gene and segmental jumping translocation following 15;17 translocation and the FISH analysis will be applicable for classification of AMLM3.
\end{abstract}

Keywords: 15; 17 chromosomal translocation, acute myelocytic leukemia (AML), acute promyelocytic leukemia (APL), chromosome instability, PML, RARa, FISH

\section{Introduction}

Acute myelocytic leukemia (AML) French-AmericanBritish (FAB) M3 is a clinically heterogeneous disease. Two cytological forms, M3 and M3 variants in FAB classification are distinguished. AMLM3 cells are characterized containing bundles of Auer rods (faggots) randomly distributed in the cytoplasm in the bone marrow and sometimes in the peripheral blood. AMLM3 variant form accounts for $15-20 \%$, characterized by minimal rather than excessive granulation and very strong myeloperoxidase and no visualization of Auer rods. AMLM3 variant case has sometimes 15;17 translocation. Most of AMLM3 also called acute promyelocytic leukemia (APL), which represents about $10 \%$ of $A M L$ and about $70 \%$ of APL patients are characterized by a reciprocal translocation $\mathrm{t}(15 ; 17)$ (q22;q21), (The $4^{\text {th }}$ International Workshop on Chromosomes in Leukemia, 1984). The translocation leads to the disruption of promyelocytic leukemia $(P M L)$ gene and retinoic acid receptor alpha $(R A R \alpha)$ gene followed by reciprocal $P M L-R A R \alpha$ and $R A R \alpha-P M L$ fusion genes. $P M L-R A R \alpha$ fusion gene is found in about $90 \%$ of the APL patients (Sakurai et al.,
1982). APL cells present with a unique sensitivity to the differentiating action of all-trans retinoic acid (ATRA) (Burnett et al., 1999). The $t(15 ; 17)$-positive AML is classified in a subtype of AML with recurrent genetic abnormalities in WHO Classification (WHO Classification of Tumours, 2007).

As it was described for chronic myelocytic leukemia, which associates with $t(9 ; 22)$ and AMLM2with $t(8 ; 21)$, complex or variant $15 ; 17$ translocation has been reported in very small percent (about 1-2\%) of APL (Sakurai et al., 1982; 4th Intl. Workshop on Chromosomes in Leukemia, 1984). Fluorescence in situ hybridization (FISH) can detect cryptic, submicroscopic rearrangements. In present study, we analyzed 39 AMLM3 patients including three cases of complex or variant $15 ; 17$ translocation by fluorescence in situ hybridization (FISH) using both probes of $P M L-R A R \alpha$ and $R A R \alpha-P M L$ chimeric genes, which are formed by standard $15 ; 17$ translocation to identify mechanism for formation of complex or variant $15 ; 17$ translocations as well as to classify of AMLM3 for clinical use.
Research article

(C)Indian Society for Education and Environment (iSee)
"15;17 translocation in leukemia" http://www.indjst.org
K.Tanaka et al. Indian J.Sci.Technol. 
Table 1. Summary of results of FISH and RT-PCR analyses on PML-RARaand RARa-PML chimeric genes in 39 AMLM3 patients and 2 other type $A M L$ patients

\begin{tabular}{|c|c|c|c|c|c|c|c|}
\hline $\begin{array}{c}\text { Dix.AML } \\
\text { M3 }\end{array}$ & $\begin{array}{l}P M L- \\
R A R \alpha\end{array}$ & $\begin{array}{l}R A R \alpha \\
-P M L\end{array}$ & $\begin{array}{c}\mathrm{t}(15 ; 17) \\
\mathrm{t}(\alpha ; 15 ; 17) \\
\text { ins }(15 ; 17)\end{array}$ & $\begin{array}{c}{ }^{* 1} \mathrm{RT}-\mathrm{PCR} \\
\text { Of } P M L- \\
R A R \alpha\end{array}$ & $\begin{array}{l}{ }^{2} \text { DNA } \\
\text { analysis } \\
\text { on } R A R \alpha\end{array}$ & $\begin{array}{c}\text { No. of } \\
\text { analyzed } \\
\text { patients } \\
(\%)^{\star 3}\end{array}$ & $\begin{array}{c}\text { Total } \\
\text { No. of } \\
\text { patients }\end{array}$ \\
\hline+ & + & + & + & $(+)$ & $(+)$ & $16(51.6)$ & \multirow{3}{*}{31} \\
\hline+ & + & + & - & $(+)$ & $(+)$ & $9(29.0)$ & \\
\hline+ & + & - & + & $(+)$ & $(+)$ & $6(19.4)$ & \\
\hline+ & - & - & - & $(-)$ & $(-)$ & 8 & 8 \\
\hline- & & & & $(-)$ & $(-)$ & 2 & 2 \\
\hline
\end{tabular}

${ }^{* 1,2}$ Several patients only were analyzed by RT-PCR and Southern blotting of RARa gene, in present study; +, (+):Positive results, -, (-);Negative results; Dix.: diagnosis, Discrepant results were observed in these patients with FISH and RT-PCR analyses on PML-RARdand RARo-PML chimeric gene, which

are shown in bold letter. ${ }^{3}$ Percentage in 31 AML M3 patients with PML-RARachimeric gene

We analyzed 39 AMLM3 patients with or without simple or complex 15;17 translocation, by metaphase and interphase FISH methods using both of PML-RAR $\alpha$ and RARa-PML chimeric probes. Thirty-one patients had $P M L-R A R \alpha$ gene positive, but 6 (19.4\% of the $31 P M L-$ $R A R \alpha$ positive AML M3 patients) did not show $R A R \alpha$ $P M L$ chimeric signal. Present $\mathrm{FISH}$ analysis demonstrated the reason why the six AMLM3 patients showed such a discrepant results and that the region involving $R A R \alpha$ gene may be higher chromosome instability in AMLM3 patients.

\section{Materials and methods Patients}

Thirty nine AMLM3 patients (22 males and 17 females) were used for present FISH study, most of whom had standard or complex 15;17 translocation, normal karyotype and others. All of the patients had the typical and hematological features of AML M3 or M3 variant. In addition, another 2 hematological disease patients, one each of AMLM4 and AMLM5), who had chromosome aberrations of chromosome 15 or 17 in the chromosome analysis at diagnostic stage, were analyzed by FISH or real time polymerase chain reaction (RT-PCR) or Southern blotting DNA analysis on RAR $\alpha$ gene.

\section{Chromosome analysis}

Chromosome analyses were performed by G-banding method in all of the 41 AML patients, including 29 AMLM3 with standard 15;17 translocation, 2 AML M3 with complex 15;17 translocation including insertion and 8 with normal karyotype or other abnormal karyotypes with diagnosis of $\mathrm{FAB} M 3$ at onset or at relapse stage. Two patients were diagnosed as AML M4 and M5. Bone marrow cells were separated by Ficoll-hypaque sedimentation and monoblastic cells were cultured for $24 \mathrm{~h}$. Chromosome preparations were prepared as standard method and pretreated according to the International System for Human Cytogenetic Nomenclature (ISCN, 2005).

RNA and DNA analyses

RNA's from 4 of the 6 AMLM3 patients with standard or complex $\mathrm{t}(15: 17)$ and other 10 AMLM3 patients were analyzed by reverse transcriptase- polymerase chain

Research article

CCIndian Society for Education and Environment (iSee)

\section{in 13 AMLM3 patients (Tashiro et al.,1993).} FISH analysis

All of the 41 AML patients' samples were analyzed by G-banding method last fifteen years. Stored fixative solutions (3:1 methanol and acetic acid) from bone marrow cells were used for FISH on metaphases and interphase cells. Fresh bone marrow cells were also used for interphase FISH method, in which samples were treated with fixative solution immediately after receiving sample. Prepared slide were treated with RNase (100 $\mu \mathrm{g} / \mathrm{ml})$ for $1 \mathrm{~h}$ and treated by pepsin $(10 \mathrm{mg} / \mathrm{ml}$ ) for $10 \mathrm{~min}$ and fixed with formaldehyde before hybridization. Each labeled 150-300 ng probe was denatured for 5 minutes and hybridized with $70 \%$ of formamide solution in moisture chamber for 48-72h. Observation and photograph with dual colors were performed simultaneously under fluorescence microscopy (Olympus TA325). For microphotograph, Fujichrome 400 was used, adjusted as ASA 800. For analysis 15;17 translocation, $P M L-R A R \alpha$ and $R A R \alpha-P M L$ probes were obtained from Onco Sci. and Vysis IP companies, respectively and were used according to companies recommendation.

Then counterstained with 4',6-diamdino-2 phenylindoledihydrochloride (DAPI) $(5 \mathrm{ng} / \mathrm{ml}$, Sigma, St Louis). The signals were scored under fluorescence and laser scanning confocal microscopes (Olympus, Tokyo) using appropriate absorption and excitation filters. PML$R A R \alpha$ and $R A R \alpha-P M L$ chimeric gene-positive cells were indicated by fusion of red and green signals resulting in a yellow signal. The 10-20 metaphases and 200-250 interphase cells were scored to estimate the frequencies of splitting signal of $P M L-R A R \alpha$ or $R A R \alpha-P M L$ chimeric gene in leukemic cells in each patient. For the interphase nucleus $\mathrm{FISH}$, cut-off values of more than $3.8 \%$ and $4.13 \%$ (mean \pm 2 standard deviation) of PML-RAR $\alpha$ and $R A R \alpha-P M L$ chimeric gene signals in all of observed cells, respectively, was used for classification as 15;17 translocation positive in each patient (Tanaka et al.,1997a,1999). Whole chromosome painted probes of chromosomes 15 and 17 were not used in present study. 
Indian Journal of Science and Technology

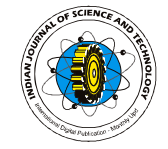

Table 2. Karyotypes and interphase FISH results in six AML M3 patients, who had PML-RARachimeric gene, but not RARa-PML chimeric gene

\begin{tabular}{|c|c|c|c|}
\hline $\begin{array}{l}\text { Case } \\
\text { No. } \\
\text { Sex/age }\end{array}$ & Karyotype & $\begin{array}{l}\text { Percent of leukemic cell signals with } \\
\text { positive }(+) \text { chimeric gene } \\
P M L-R A R \alpha \text { al } R A R \alpha-P M L\end{array}$ & $\begin{array}{l}\text { Expression of } P M L-R A R \alpha \\
\text { chimeric gene by RT-PCR } \\
+: \text { positive expression }\end{array}$ \\
\hline $1 \quad M 47$ & $46, \mathrm{XY}, \mathrm{t}(15 ; 17)(\mathrm{q} 22 ; \mathrm{q} 21)$ & $96.3 \% / 0.5 \% \quad(+/-)^{* 1}$ & + \\
\hline $\begin{array}{l}2^{*^{2}} \mathrm{~F} \\
30\end{array}$ & $\begin{array}{l}46, X X, \operatorname{add}(1)(q 44), \operatorname{add}(6)(q 12), \\
\operatorname{add}(7)(q 36), t(15 ; 17)(q 22 ; q 21)\end{array}$ & $93.9 \% / 0.0 \%$ & + \\
\hline $3 \mathrm{~F} 44$ & $\begin{array}{l}\text { 46, XX, t(1;20;4)(q25; p13; q21),t(15; } \\
\text { 17)(q22; q21) }\end{array}$ & $89.9 \% / 1.7 \% \quad(+/-)$ & + \\
\hline $4 \quad$ M 59 & $48, X Y,+8, t(15 ; 17)(q 22 ; q 21),+21$ & $98.7 \% / 0.5 \%$ & + \\
\hline $\begin{array}{l}5^{* 4} M \\
23\end{array}$ & $\begin{array}{l}46, \mathrm{XY}, \mathrm{t}(1 ; 7)(\mathrm{q} 21 ; \mathrm{p} 15), \mathrm{t}(3 ; 15 ; 17)(\mathrm{q} 21 ; \\
\mathrm{q} 21 ; \mathrm{q} 23), \text { add }(13)(\mathrm{q} 22)\end{array}$ & $85.6 \% / 4.4 \% \quad(+/-)$ & not done \\
\hline $6^{* 5} \mathrm{~F} 52$ & $\begin{array}{l}49, X X, \text { ins }(15 ; 17)(q 22 ; q 11 q 25),+3 \\
\text { mars[30]/ } 47, X X, t(15 ; 17)(q 22 ; q 21)[33] *^{3}\end{array}$ & $78.0 \% / 2.4 \% \quad(+/-)$ & not done \\
\hline \multicolumn{4}{|c|}{ 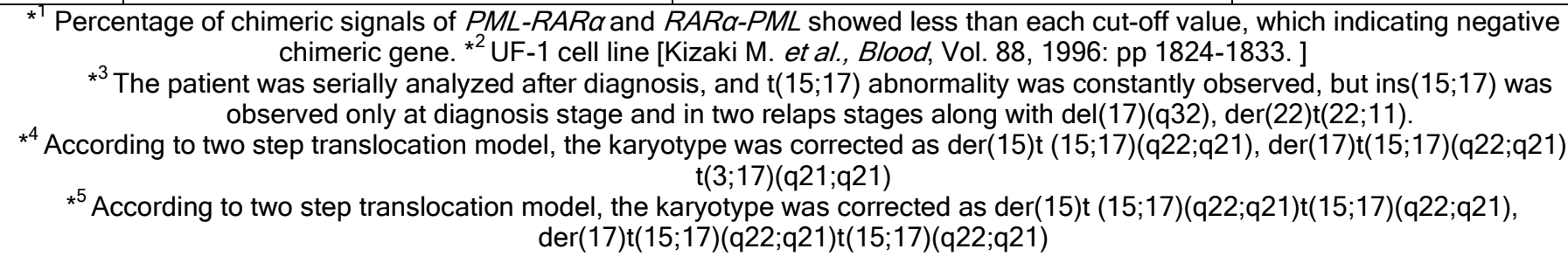 } \\
\hline
\end{tabular}

\section{Results}

Chromosome, FISH, RNA and DNA analyses on AMLM3 patients has been portrayed. Summary of chromosome and FISH analyses on 41AML patients (39

AMLM3 and one each of AMLM4 and M5) with simple or complex $t(15 ; 17)$ and others are shown in Table 1 in addition to the results of RNA and DNA analyses. Two patients who were diagnosed as AML M4 and M5 had $\mathrm{t}(14 ; 17)(\mathrm{q} 32 ; \mathrm{q} 21)$ and $\mathrm{t}(11 ; 17)(\mathrm{q} 23 ; \mathrm{q} 21)$ with $M L L$ gene rearrangement, respectively. Chimeric gene $P M L-R A R \alpha$ and $R A R \alpha-P M L$ were not detected by FISH. Out of the 39 AMLM3 patients, 31 patients had reported positive for $P M L-R A R \alpha$ gene, but eight patients had not. Another nine patients showed both $P M L-R A R \alpha$ and $R A R \alpha-P M L$ chimeric gene by $\mathrm{FISH}$, but not $\mathrm{t}(15 ; 17)$ translocation, although they were clinically and cytologically diagnosed as APL. The eight AML M3 patients did not have neither $\mathrm{t}(15 ; 17)$ translocation, $P M L-R A R \alpha$ or $R A R \alpha-P M L$ chimeric gene. G-banding analysis on the 8 AML M3 patients revealed that $(11 ; 17)(\mathrm{q} 23 ; \mathrm{q} 21) ; \mathrm{t}(9 ; 14) ; \mathrm{t}(13 ; 14)$, $\operatorname{add}(17)(\mathrm{p} 11) ;-Y,-21$ in each patients and remaining 4 patients had normal karyotype. The patient having $\mathrm{t}(11 ; 17)(\mathrm{q} 23 ; \mathrm{q} 21)$ showed chimeric PLZF-RARa by another molecular study, which indicated that these 8 AML M3 patients contained clinically and cytologically identified AML M3 variant as well as non-classical APL with translocation of $R A R \alpha$ at $17 \mathrm{q} 21$.

Of interest, 6 of the $31 P M L-R A R \alpha$ positive AMLM3 patients $(19.4 \%)$ did not show $R A R \alpha-P M L$ chimeric signal. Conventional G-banding analysis revealed the 6 patients had abnormalities of simple 15;17 translocation in bone marrow cells in almost all metaphases in 4 patients, complex 15;17 translocation in 2 patients (one of them had insertion 15;17) and one patient had normal karyotype (Table 2). Expression of $P M L-R A R \alpha$ chimeric gene was confirmed by RT-PCR method in 4 of the 6 patients (no.1, 2, 3 and 4), whose RNA samples were available (Table 2). One patient (no.1) had simple $t(15 ; 17)$, but other three patients (nos.2, 3, 4) showed standard $t(15 ; 17)$ translocation, along with extra chromosome aberrations such as add(1), add(6), add(7), $\mathrm{t}(1 ; 20 ; 4)$ and trisomy 8 in addition to standard $t(15 ; 17)$.

The no.5 patient's karyotype also showed many abnormalities, which had complex 15;17 translocation, $\mathrm{t}(3 ; 15 ; 17)$ which involved chromosome 3 as a third chromosome, in addition to $t(1 ; 7)$ and add(13) (Fig.1b). Present metaphase FISH analysis revealed that the direction of movement of each chromosome segment involving 3' or 5'-PML on chromosome 15 and that of involving 3' or 5'-RARQ on chromosome 17 showed a quite consistent rule in these complex 15;17 translocation and insertion 15;17. The patient (case no. 5) with complex chromosome translocation $\mathrm{t}(3 ; 15 ; 17)$ had PMLRAR $\alpha$ chimeric signal in $85.6 \%$ and RARa-PML chimeric signal in $4.4 \%$ of observed interphase cells, which was less than the cut-off level. Another patient (no.6) had insertion $15 ; 17$ along with standard $t(15 ; 17)$ (Fig.1a), who had PML-RAR $\alpha$ chimeric signal in $78.0 \%$ and RARa-PML chimeric signal in $2.4 \%$ of observed interphase cell. These six patients (no.1-6) had 78.0 to $98.7 \%$ of PMLRARa chimeric gene signal of observed interphase cells, but only $0-4.4 \%$ of RARa-PML chimeric gene signal. 
Fig. 1.a,b. Representative G-banded karyotype from two AML M3 patients(case nos. 6 and 5) including (a) insertion (15;17), ins (15;17)(q22; q11q25) and (b)complex t(3;15;17) translocation, t(3;15;17)(q21;q22;q23). Arrow shows abnormal chromosome.

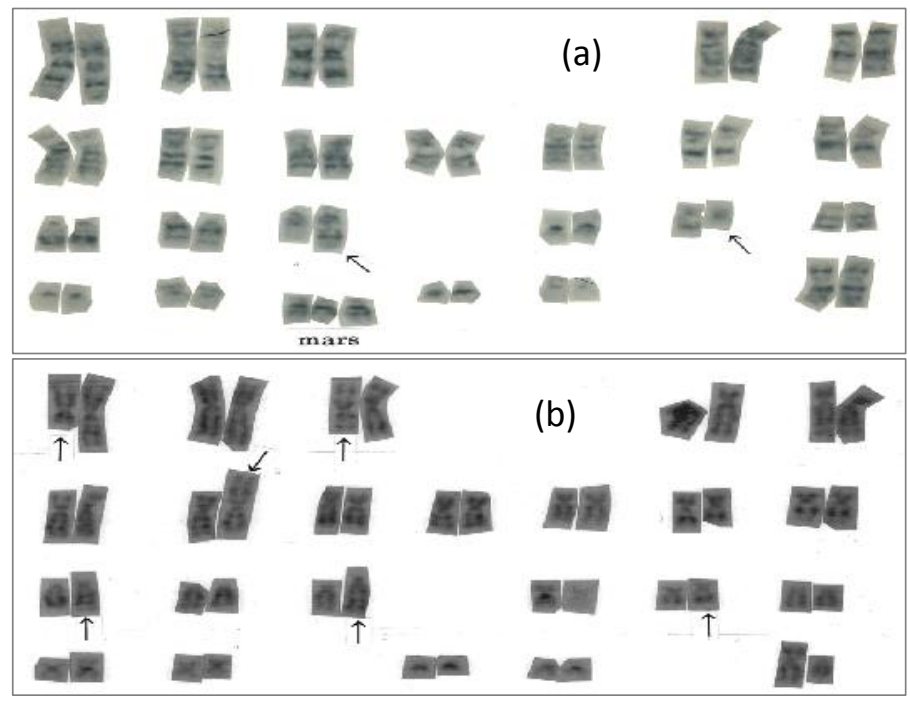

Standard translocation $\mathrm{t}(15 ; 17)$ leads formation of both $P M L-R A R \alpha$ and $R A R \alpha-P M L$ chimeric gene on derivative chromosome 15 [der(15)] and derivative chromosome 17 [der(17)], respectively, where 3'-RARa on chromosome 17 moves to chromosome 15 and joins with 3'- $P M L$ and forms $P M L-R A R \alpha$ chimeric gene, on the while 5'-PML on chromosome 15 moves to chromosome 17 and joins with 5'-RAR $\alpha$ and forms $R A R \alpha-P M L$ chimeric gene. Summary of FISH results in both PML-RARa and RARa-PML chimeric gene probe, locating on chromosomes 15 and 17 in the 6 AML M3 patients is shown in Table 2. PML-RARa chimeric gene always locate on der(15) same as those of other complex 15;17 as well as standard 15;17 translocations. PML-RAR $\alpha$ signal on $\operatorname{der}(15)$ chromosome was detected, while $R A R \alpha-P M L$ chimeric gene on $\operatorname{der}(17)$ was not, although 3' PML signal only observed on $\operatorname{der}(15)$ in all of the 6 patients (case nos.1-6). These FISH results indicate that all of these 6 patients might have a deletion of 5'-side region from break point clustering region of $R A R \alpha-P M L$ chimeric gene on $\operatorname{der}(17)$ chromosome, which contains 5 $R A R \alpha$ gene (Fig.2).Representative interphase FISH signals of patient no. 1 are shown that no $R A R \alpha-P M L$ chimeric gene signal on most of interphase cells, although 5'RARasignal retained (Fig.3).

Presumable mechanisms for the development of the loss of the RARa-PML chimeric gene in the process of formation of the complex translocation of $t(3 ; 15 ; 17)$ are diagramed in Fig.4a, b. Three mechanisms will be considerable to explain how complex translocation such as $t(15 ; 17), t(9 ; 22), t(8 ; 21)$ and so on is formed, which are one way translocation, two step translocation and insertion (Calabrese et al., 1996; Miyazaki et al., 2007; Tanaka et al., 2000, 2001, 2012a). In one way translocation model for the formation of complex Research article CCIndian Society for Education and Environment (iSee)
Fig. 2. Scheme of PML-RARaand RARa-PML chimeric genes formed on der(15) and der(17) chromosomes in $15 ; 17$ translocation. About $20 \%$ of $A M L M 3$ patients with

$P M L-R A R \alpha$ chimeric gene did not have RARa-PML chimeric gene by FISH, probably because 5'RARa gene region is deleted on der(17) chromosome.

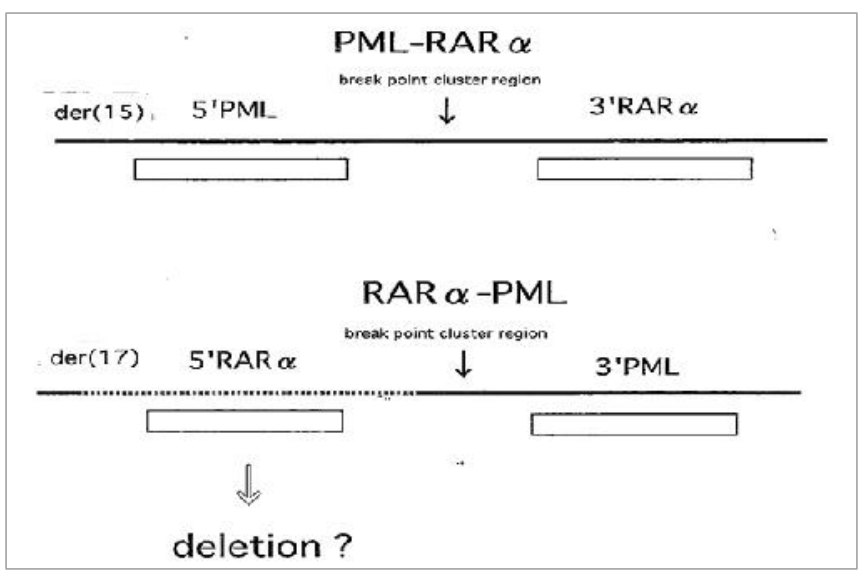

Fig. 3. (A) FISH signals on interphase cells from $A M L M 3$ patient with deletion of 5'RARd in 15;17 translocation. Only one blue signal is shown in a nucleus, indicating deletion of 5 , RARaregion on der(17) chromosome.All of the 6 patients listed in Table 2 had a similar FISH signal pattern. (B) FISH signals on interphase cells from AML M3 patient with standard 15;17

translocation. Fusion signal with blue and red colors in a nucleus shows RARa-PML chimeric gene on der(17) chromosome. Blue and red signals show 5'RARa and 3'PML probes, respectively. Arrow shows fusion signal.
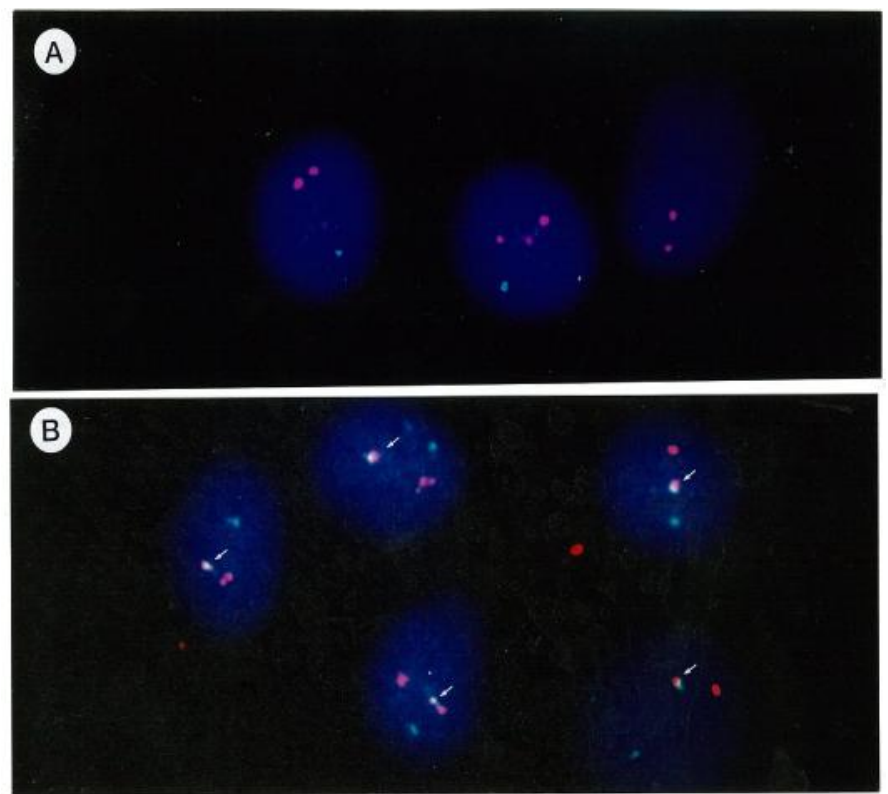

translocation of $\mathrm{t}(\alpha ; 15 ; 17)$, where $\alpha$ is any chromosome, which develops at a same time and a segment of chromosome der(15) moves to third chromosome, and a segment on the third chromosome backs to chromosome $\operatorname{der}(17)$, where a translocated chromosome segment is circulated. The segment, which is not involved 5'-RAR $\alpha$

"15;17 translocation in leukemia" http://www.indjst.org
K.Tanaka et al. Indian J.Sci.Technol. 
Indian Journal of Science and Technology

Fig. 4a. One step translocation model for complex translocation of $t(3 ; 15 ; 17)$ in case 5 . Region involving 3'RARa moves to chromosome 15, and the distal segment of der(15) chromosome moves to third chromosome 3, and at a same time a part of chromosome 3 back to chromosome 17.

Chromosome segment of each chromosome circulates among these three chromosomes. According to the one step translocation model, RARa-PML chimeric gene is not always sformed because 5' $R A R \alpha$ region retains on der(15)

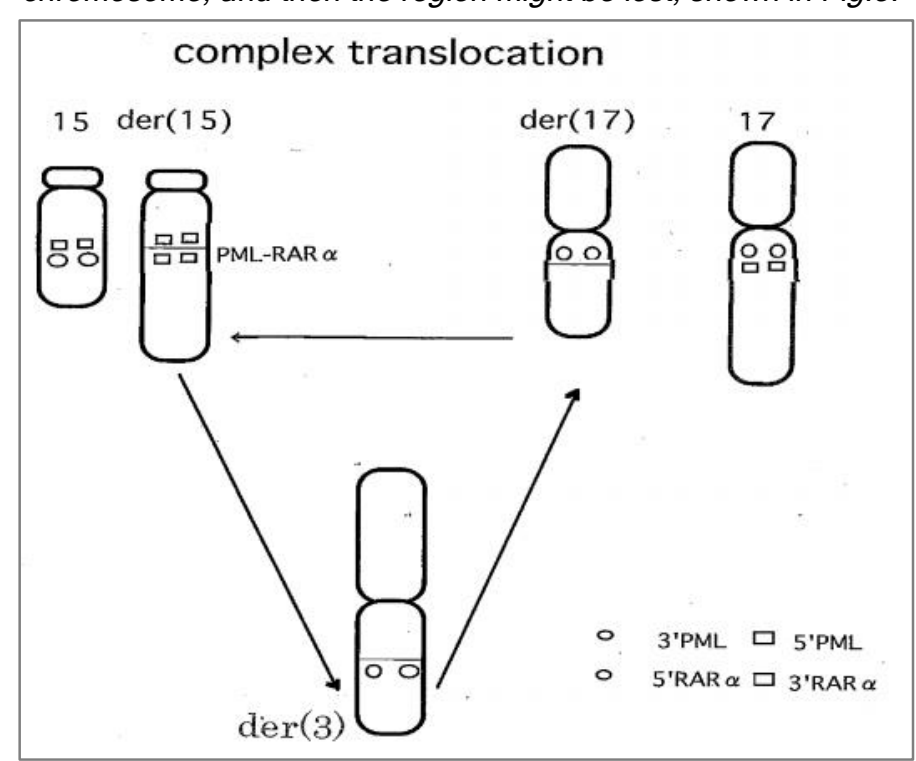

Fig. 4b. Two step translocation model for complex translocation of $t(3 ; 15 ; 17)$ in case 5 . Translocation occurs two times sequentially in this model. PML-RARaand RARa-PML chimeric genes form on der(15) and der(17) chromosomes, respectively, in 15;17 translocation in the first step, followed by translocation between der(17) chromosome and chromosome 3 in second step. Deletion of 5' RARa region

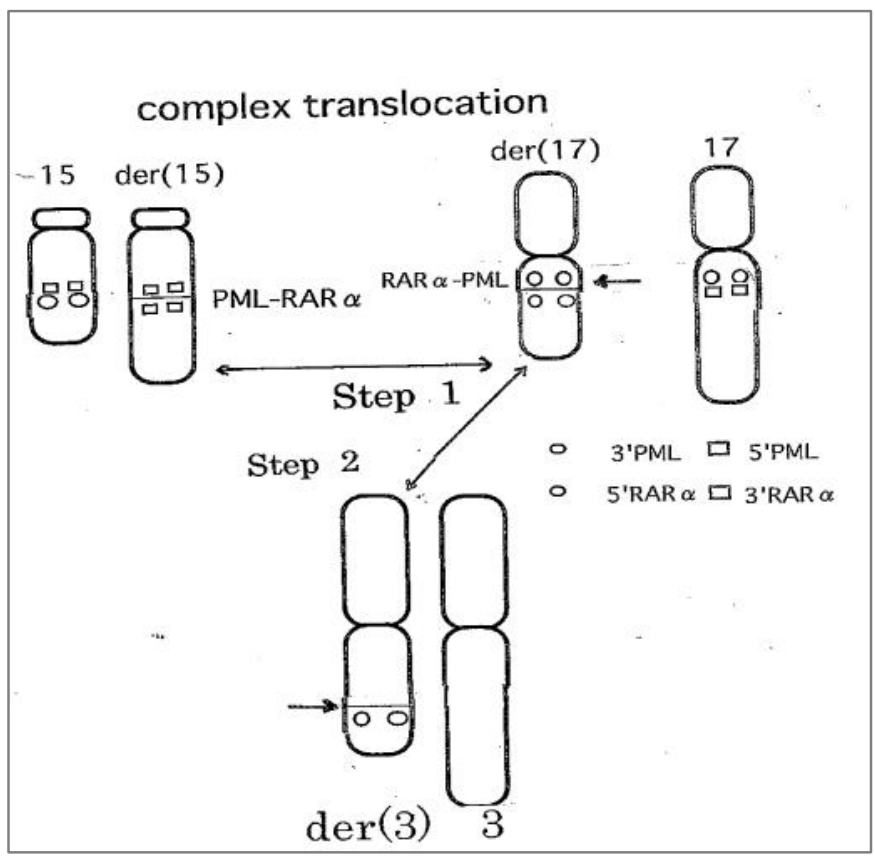

chromosome, and then the region might be lost, shown in Fig.3. might develop in the second step, shown in Fig. 3.

Vol. 5 No. 9 (Sep. 2012)

ISSN: 0974- 6846

Fig.5a. One step translocation model for insertion of $15 ; 17$ in case 6 . Chromosome segment involving 17q11q25 inserts to chromosome 15, where 3'RARa moves to der(15) chromosome and 5'RARa retains on der(17) chromosome. In this model, RARa-PML chimeric gene is not always formed because 5' $R A R \alpha$ region retains on der(15) chromosome, then the region might be lost, shown in Fig. 3.

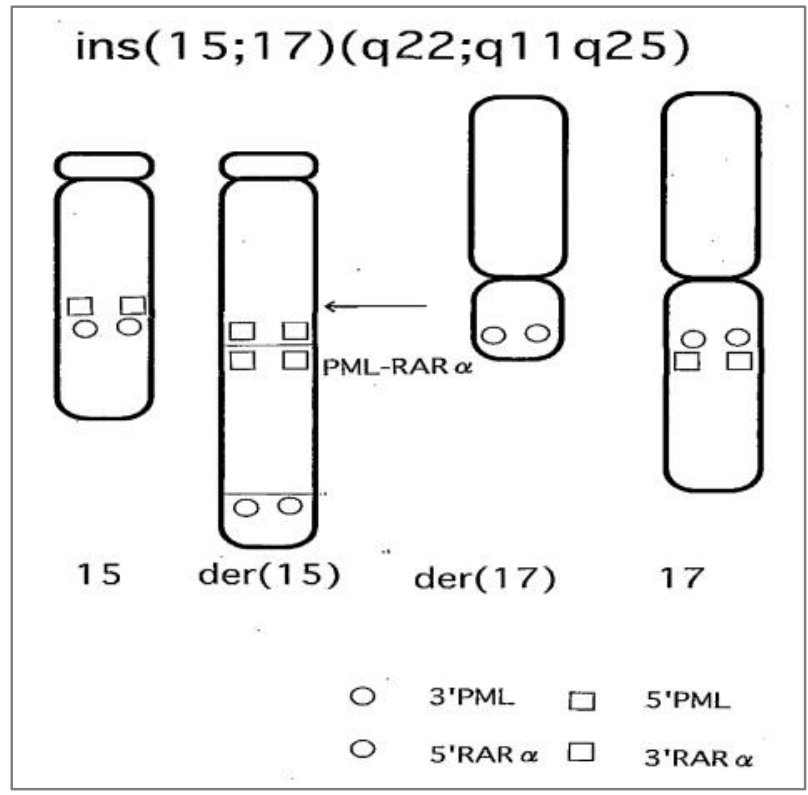

Fig.5b. Twostep translocation model for insertion of $15 ; 17$ in case 6 . Translocation occurs two times sequentially in this model. PML-RAR a and RARa-PML chimeric genes form on der(15) and der(17) chromosomes, respectively, in 15;17 translocation in the first step, followed by translocation between der(17) and der(15) chromosomes in second step. In the second step, deletion of 5' RARa region might develop, shown in Fig.3.

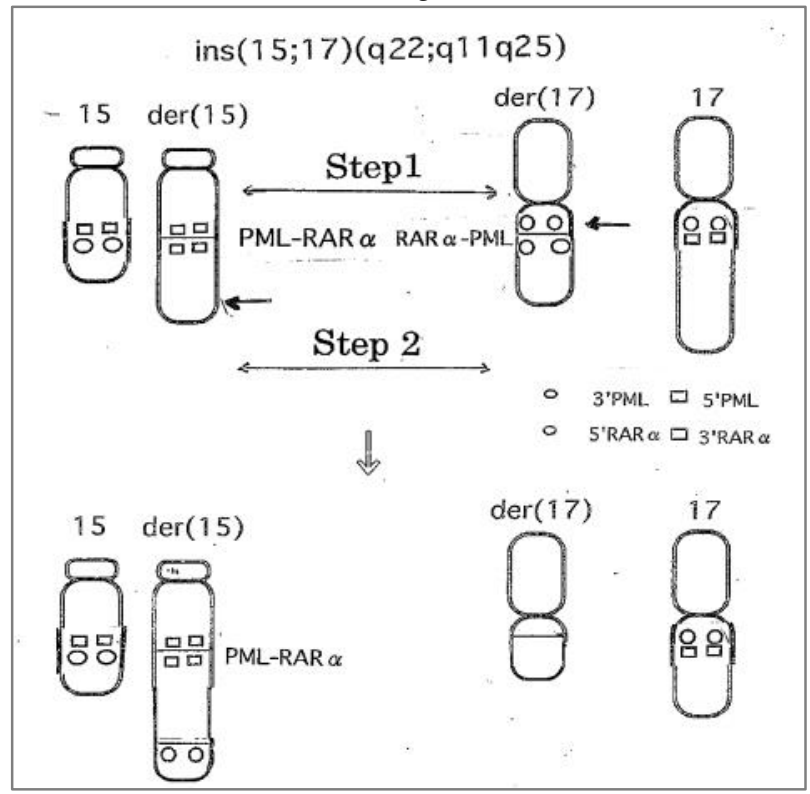

K.Tanaka et al. Research article COIndian Society for Education and Environment (iSee) 
region on $\operatorname{der}(17)$ chromosome, moves to chromosome der(15), where 5'-RARa region retains on der (17) chromosome, but a segment involved 3' PML also moves to third chromosome, chromosome der(3) in this case, at a same time, resulting that $R A R \alpha-P M L$ chimeric gene is not formed (Fig. 4a). A segment involved 3'-RARa on chromosome $\operatorname{der}(17)$ moves to chromosome $\operatorname{der}(15)$ and fuses with a segment involving $5^{\prime}-P M L$, as a result of that $P M L-R A R \alpha$ chimeric gene is formed on chromosome $\operatorname{der}(15)$ (Fig.4a).

In insertion model for the formation of ins $(15 ; 17)$ in patient no.6, the segment, which is not involved is 5'RAR $\alpha$ region on the $\operatorname{der}(17)$ chromosome, where 5'RAR $\alpha$ region retains on $\operatorname{der}(17)$ chromosome, inserts to der(15) chromosome and as a result of that $R A R \alpha-P M L$ chimeric gene is not formed (Fig. 5a). A segment involved 3'-RARa on der (17) chromosome moves to chromosome $\operatorname{der}(15)$ and fuses with a segment involving 5'-PML and as a result of that $P M L-R A R \alpha$ chimeric signal is formed on $\operatorname{der}(15)$ chromosome (Fig.5a). In these two patients explain the models, one is that both breakpoints on der (17) chromosome for formation of $\mathrm{t}(3 ; 15 ; 17)$ and ins $(15 ; 17)$ might be far from the common $R A R \alpha$ gene region of standard $t(15 ; 17)$ translocation, and another is that a deletion of region involving the chimeric gene of 5 '$R A R a$ gene is induced.

\section{Discussion}

Importance of PML-RARQ and RARQ-PML chimeric gene

In acute promyelocytic leukemia (APL), a subtype of AML with $\mathrm{t}(15 ; 17)$ translocation and PML-RAR $\alpha$ in WHO classification (WHO Classification of Tumours, 2007), chimeric genes are characterized by the $15 ; 17$ translocation which generates both of the $P M L-R A R \alpha$ and $R A R \alpha-P M L$ chimeric genes. The resulting PML-RAR $\alpha$ fusion protein expression correlates with that of promyelocytic phenotype and blast differentiation in response to retinoic acid. PML-RAR $\alpha$ chimeric protein is implicated in APL pathogenesis. Indeed, PML-RARa blocks terminal cell differentiation by a dominant-negative effect. Transgenic mice expressing PML-RARa shows an altered myeloid development, some of them eventually developed AML like APL cells (Brown et al., 1997). Taken together, PML-RAR $\alpha$ chimeric protein plays a crucial role in pathogenesis of APL, whereas the role of RARa-PML chimeric protein is still controversial. Comparative in vitro study to observe response to ATRA treatment of APL cells with PML-RAR $\alpha$ or RAR $\alpha-P M L$ chimeric protein revealed that PML-RAR $\alpha$ alone is sufficient for APL phenotype, which is sensitive to ATRA, but RARa-PML is resistant to ATRA. In vitro response study to ATRA in an APL case expressing only a RARa-PML fusion transcript showed resistance to ATRA (Mozziconacci et al., 1998). On the other hand, the third type of bcr2 or variant (V)type isoform of $R A R a$ gene, accounting for $10 \%$ in APL, decreased sensitivity to ATRA (Burnett et al., 1999; Gu et al., 2002). Lower expression of PML-RARa protein in (case no.5 and 6), two possibilities will be considerable to

early myeloid cells was found to have a higher incidence of an APL-like phenotype compared to an earlier transgenic model. RAR $\alpha-P M L$ chimeric protein increases the penetration of the leukemic phenotype in PML-RARa transgenic mice, which suggested a cooperating role of RARa-PML chimeric protein with PML-RARa protein (Walter et al., 2007).

As the PML-RARa fusion protein retains the RARa DNA and retinoic acid binding domains and the interface of dimeraization with RXRs, a family of retinoic acid receptors, activating as co-factors for other nuclear receptors such as D3 and thyroid hormone receptors, it can transactivate retinoic acid target genes and bind RXRs and retinoic acid. The crucial mechanism underlying PML-RAR $\alpha$ oncogenic activity is interplay with RXRs and deregulation of transcription factor, RARa, though its fusion with dimerization interfaces of another nuclear protein, PML (Grignani et al., 1996). Thus, the biological importance of RARa has been highlighted. In addition, in a small subset (1-2\%) of patients with APL with variant chromosome translocations $\mathrm{t}(11 ; 17)(\mathrm{q} 23 ; \mathrm{q} 21), \mathrm{t}(5 ; 17)(\mathrm{q} 35 ; \mathrm{q} 21), \mathrm{t}(11 ; 17)(\mathrm{q} 13 ; \mathrm{q} 21)$, dup(17)(q21-23) or normal karyotype, the RARa gene is the common target and is fused to corresponding partner genes PLZF, NPM, NuMA and STAT5b (Wells et al., 1997; Bennett et al., 2000; Grimwade et al., 2000; Redner 2002; Dong \& Tweardy, 2002). All these results of variant APL also emphasize the importance of the RARa gene in the pathogenesis of APL. These results implicate that PML-RARa fusion protein alone may not be sufficient for full leukemic transformation. On the other hand, clinical study was shown that $R A R \alpha$ chimeric gene expression does not affect patient outcome or complications (Li et al., 1997). Reciprocal transcripts are detected in only $81 \%$ of patients (Grimwade et al., 1996). Deletion of RARa-PML

Fig. 6. Classification of $A M L M 3$, which is clinically and cytologically heterogeneous disease, including APL and M3

variant. The disease can be classified by several genetic methods such as DNA rearrangement of RAR agene, and FISH analyses of RAR $\alpha-P M L$ and PML-RAR $\alpha$ chimeric genes.

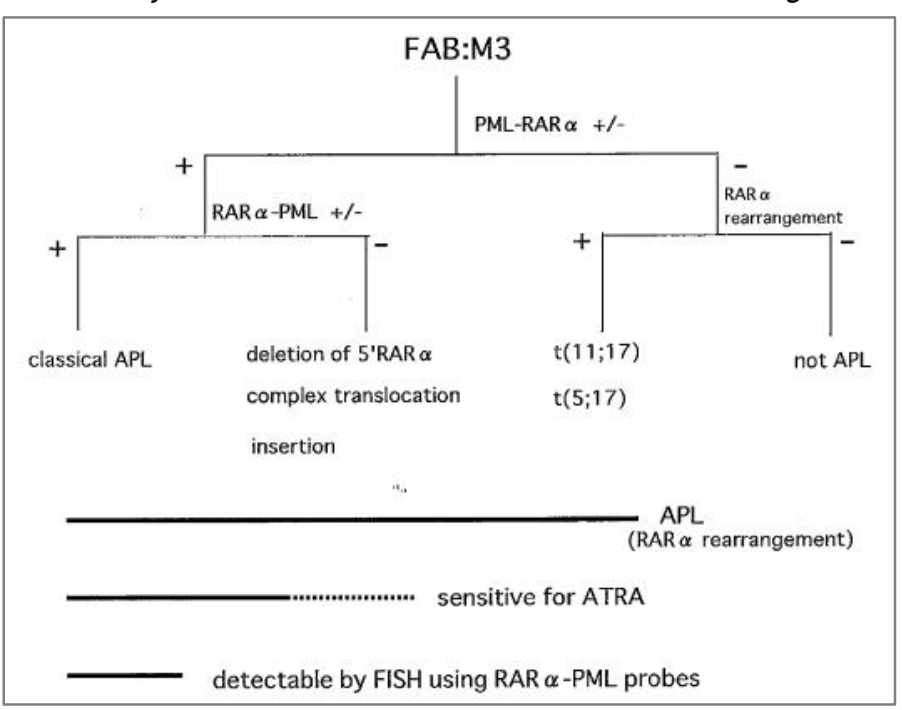


chimeric gene in about $20-25 \%$ of AMLM3 has been reported by several authors (Walz et al., 2010). These findings suggested a possibility that 5' RARa deletion cases might have a distinct clinical symptom from no deletion cases in the PML-RARa chimeric gene positive AML M3.

Furthermore, the physiological function of PML itself is unknown. Its $\mathrm{N}$-terminal portion includes three cysteine/histidine-rich regions and C-terminal to the cysteine/histidine clusters is a coiled-coil domain, which is retained in the PML-RARa fusion protein and is sufficient for oncogene activation of the RAR $\alpha$ (Occhinorelli et al., 2011). Increase of PML nuclear bodies in cultured human B-lymphocytes were observed after radiation exposure or $\mathrm{Y}$-IFN treatment, and after adding serum from severe aplastic anemia patients (Liu et al., 2008a, 2008b), which implicates another diverse functions of PML proteins such as apoptosis after DNA damage so on (Yang et al., 2002, Hofmann \& Will, 2003), autophagy (Huang et al., 2011) and senescence (Pearson et al., 2001).

Mechanism for formation of complex 15;17 translocation and insertion 15:17

The mechanism for formation of complex $15 ; 17$ translocation may be explained by three different mechanisms; (1) One step translocation occurred among three chromosomes of chromosomes 15, 17 and third chromosome $(\alpha)$ at same time, where chromosome 17 moves to chromosome 15, and chromosome 15 moved to third chromosomes, serially. The translocated chromosome segments are circulated. This model has been shown in Fig.4a. In this model, breakpoints are located within PML, RARa and unknown gene on third chromosome. (2) A two-step translocation, i.e. in a first, a typical 15; 17 translocation was occurred between chromosomes 15;17, consisting of PML-RAR $\alpha$ fusion gene on chromosome 15, followed by a second translocation between the aberrant $\operatorname{der}(17)$ chromosome and third chromosome 3 . Two step translocation models for case 5 are shown in Fig.4b. Second breakpoints locate on telomeric or cenromeric site of $R A R \alpha$ gene on der (17) chromosome and within a region of the third chromosome 3 in this model. PML-RAR $\alpha$ and RARa-PML chimeric signals locate on $\operatorname{der}(15)$ or $\operatorname{der}(17)$ chromosome, respectively. Second breakpoint might be telomeric or centromeric region of $R A R \alpha$ gene in case 5 having $\mathrm{t}(3 ; 15 ; 17)$ translocation. 5' RARaregion of RARaPML chimeric signal locating on der(17) chromosome might be lost in the step of second translocation. We have another complex cases, who had $t(15 ; 17)(q 22 ; q 21) t(X ; 15)(q 21 ; q 22)$ but the patient was not analyzed by FISH and RT-PCR methods. So many cases with complex 15; 17 translocation have been reported (Bjerrum et al., 1987; Grimwade et al., 1997; Gogineni et al., 1998; Yamamoto et al., 1998; Miyazaki et al., 2007). (3) Insertion of the relevant RARa segment from chromosome 17 to the $P M L$ gene on chromosome 15 at same time, followed by ins $(15 ; 17)$, of which model has been shown in Fig. 5a. In this model, breakpoints are also located within PML, RARa and unknown region on der (17) chromosome.

Furthermore, mechanisms for chromosome formation of ins $(15 ; 17)$ found in case 6 might be explained by the two-step translocation model, which is shown in Fig. 5b. In the case, first a typical 15; 17 translocation occurred between chromosomes 15 and 17, consisting of $P M L-$ $R A R \alpha$ fusion gene on der(15) chromosome and RARaPML fusion gene on der (17) chromosome, followed by a second translocation between telomeric region of the aberrant der (15) and der (17) chromosomes. Second breakpoints might be located on telomeric site of der (15) and the region within $5^{\prime} R A R \alpha-3^{\prime} P M L$ chimeric gene on der (17) chromosome. 5'RARQ-3'PML chimeric gene might be split and 5'RARa signal might be lost on the der (17) chromosome, on the while 3'PML signal retained on telomeric region of der(15) chromosome. Two step translocation models for case 6 is shown in Fig. 5b. We could not determine which one or two way translocation might be associated with formation of complex translocation of $15 ; 17$ in present analysis, because precise breakpoint sites of second translocation in the complex 15;17 translocation were not analyzed using several BAC clone probes mapping near breakpoint sites on both der (15) and der (17) chromosomes. Several cases with ins $(15 ; 17)$ or ins $(17 ; 15)$ has been reported so far (Hiorns et al., 1994; Grimwade et al., 1997; Mozziconacci et al., 1998; Grimwade et al., 2000; Viguié et al., 2000; Haraguchi et al., 2008), although it remains a possibility of misidentification.

Considering from previous FISH study on CML patients with complex $t(9 ; 21)$ translocation, we predicted that complex $9 ; 22$ translocation could be formed by two step mechanism, in which translocation between der(9) or der(22) chromosome and third chromosome might occur secondary following after the first standard 9;22 translocation (Tanaka et al., 2001). Two step translocation models for complex 9;22, 8;21 and 15;17 translocations has been reported (Bjerrum et al., 1987; Calabrese et al., 1996;Tanaka et al., 2001, 2012a).In present study, case 6 had two related clones with ins $(15 ; 17)$ and $t(15 ; 17)$ (Table 2$)$, in which ins $(15 ; 17)$ may be developed secondary after primary standard 15;17 translocation. The finding supports two step translocation models. Indeed, according to one way translocation model (Fig. 4a \& Fig. 5a), all of the cases with complex $15 ; 17$ translocation or insertion 15; 17 would have no $5^{\prime} R A R \alpha-P M L$ chimeric gene. On the while, in two step translocation model (Fig. 4b \& Fig. 5b). It remains to be resolved whether all of these patients with complex translocation or insertion had 5'RAR $\alpha$ deletion and no $5^{\prime} R A R \alpha-P M L$ chimeric gene.

Chromosome instability of RARa region on der(17) chromosome
Research article

(C)Indian Society for Education and Environment (iSee)
"15;17 translocation in leukemia" http://www.indjst.org
K.Tanaka et al. Indian J.Sci.Technol. 
Present results showed that $19.4 \%$ of $P M L-R A R \alpha$ positive AMLM3 had deletion of $R A R \alpha-P M L$ chimeric gene on der(17) chromosome (Table 1), in which second breakpoints locate vicinity of $R A R \alpha$ gene. The percentage was well corresponding with other publication using double color fluorescence in situ hybridization (D)-FISH method (20\%, 40 of 200 AML M3 patients) (Amare et al., 2011). Several reciprocal translocations such as $t(12 ; 21)$, $\mathrm{t}(8 ; 21), \mathrm{t}(15 ; 17)$ and $\mathrm{t}(11 ; \alpha)(\mathrm{q} 23 ; \alpha)$ are known to be associated with submicroscopic or large deletion on the derivative chromosomes (Kolomietz et al., 2001; Moon et al., 2007; Stavropoulou et al., 2008). About 30\% of ABL1$B C R$ region on der (9) chromosome are deleted in BCRABL1 positive CML (Tanaka et al., 1993; Huntly et al., 1996). However, the clinical and prognositic values of these deletion have been inconsistent in these reciprocal translocation cases without $\mathrm{t}(9 ; 22)$ (Turner et al., 2001; Kolomietz et al., 2001). Reciprocal RNA transcripts are detected in only $81 \%$ of patients (Grimwade et al., 1996), but deletion of $R A R \alpha-P M L$ chimeric gene in about $20 \%$ of et al., 1998; Yamamoto et al., 1998; Walz et al., 2010). According to two-way translocation model, telomeric end of $\operatorname{der}(15)$ and $\operatorname{der}(17)$ chromosomes harbor second breakpoints. These results are indicting that both vicinity regions near $R A R \alpha$ gene on der(17) chromosome, which associate with primary occurred $15 ; 17$ translocation might be genetically unstable and labile to genomic instability. Then the genomic instability will induce deletion of $R A R \alpha$ $P M L$ chimeric gene, which associated with loss of 5'RAR $\alpha$ region, and second translocation between der (17) and third chromosome.

The genomic instability is also observed as segmental jumping translocation (SJT) (Tanaka et al., 1997b, 2000, 2012b; Tanaka \& Kamada, 1998). In addition to deletion of 5'RARaon der (17) chromosome, the vicinity regions of RARa move to several another chromosome region(s), this shows several extra signals by FISH analysis. Present FISH analysis revealed that metaphases from three of the 39 AMLM3 patients had two PML-RARa chimeric signals in two patients, and one extra 5'RARasignals on marker chromosome in addition to two PML-RARa chimeric signals in one patient. First and second patient's chromosome karyotype showed $\mathrm{t}(15 ; 17)$, +der (15) $\mathrm{t}(15 ; 17)$, $\mathrm{i}(17 \mathrm{q})$ and third patient showed $t(15 ; 17)+\operatorname{der}(15) \mathrm{t}(15 ; 17)$, +i[der(17) $\mathrm{t}(15 ; 17)]$, +mar and so on. Similar findings of SJT involving RARaregion had been observed in in $\mathrm{t}(15: 17)$ patients with i[der(17)t(15;17)] (Park et al., 1997; Lee et al., 2005; Luatti et al., 2008; Kim et al., 2010; Manola et al., 2010) and in an AML M5 patient (Asleson et al., 2010). These findings are again indicating that RARa region on der (17) might have higher chromosomal instability.

Furthermore, insertion of 15;17 abnormality has been infrequently reported AMLM3 patients, and the incidence was much higher than other that of $8 ; 21$ or $9 ; 22$ translocation. Unique DNA sequences might be located AMLM3 has been reported by several authors (Gogineni

on $\operatorname{der}(17)$ chromosome, which mostly associates with ins $(15 ; 17)$ or ins $(17 ; 15)$ in small cases (Grimwade et al., 1997). Increasing proportion of APL cases are therapyrelated, which develop following exposure to radiotherapy and /or chemotherapeutic agents that target DNA topoisomerase II. Topoisomerase II was directly involved in mediated breakpoint of double-stranded DNA at the observed chromosomal translocation breakpoints (Mistry et al., 2005; Hasen et al., 2008). Several chromatin structural elements including in vivo topo II DNA cleavage sites, DNase I hypersensitive sites and SARs might have been characterized for possible higher development of translocations or other type of chromosome aberrations in leukemia and other cancers at near region of $R A R \alpha$ gene. In conclusion, more dynamic chromatin change or some specific gene structure might form after initial chromosome translocation near initially occurred chromosome breakpoint regions, which may occur secondly translocation.

FISH analysis is applicable for classification of AML M3

In present FISH analysis, 9 of 39 AML M3 patients) 29.0 (\%did not have $\mathrm{t}(15 ; 17)$ by G-banding, even though $P M L-R A R \alpha$ and $R A R \alpha-P M L$ chimeric genes were detected by RT-PCR (Table 1). This can be due to either a submicroscopic insertion as demonstrated by FISH method or to the presence or the proliferation of residual normal cells. The first reason for the discrepancy can be explained as follows. There are several reports on AML M3 cases with masked 15;17 translocation (Brunel et al., 1996; Grimwade et al., 1997; Mozziconacci et al., 1998; Kohno et al., 2001; Haraguchi et al., 2008). They showed normal karyotype or variant translocation involving chromosome 15 and 17 such as $t(15 ; \alpha)$ ( $\alpha$ is any chromosome). RT-PCR and FISH analyses revealed that these patients had submicroscopic aberrations involving $P M L-R A R \alpha$ chimeric gene. These masked 15; 17 translocation might be developed by two step translocation mechanism. We have previously analyzed three masked 9;22 translocation cases showing normal karyotype by FISH using locus specific cosmid probes and whole painting probes (Tanaka et al., 2001), which indicating that these normal karyotype in CML were occurred by two step translocation, not insertion of $A B L$ gene. The second reason for the discrepancy can be explained as follows. In previous result, we found $t(15 ; 17)$-positive leukemic cells prone to have less proliferation in $24 \mathrm{~h}$ culture than normal cells, which results in higher chance of showing normal karyotype in chromosome examination (Tanaka et al., 1999). Eight AMLM3 cases had both PML-RAR $\alpha$ and RAR $-P M L$ chimeric signals by FISH, but showing no $\mathrm{t}(15 ; 17)$ translocation or normal karyotype. Hidden chromosome aberrations, which are related to less proliferation of leukemic cells in vitro culture, has been observed in showing a cytogenetically normal karyotype (Kumaravel et al., 2008).

Research article

Clndian Society for Education and Environment (iSee)

"15;17 translocation in leukemia" http://www.indjst.org
K.Tanaka et al. Indian J.Sci.Technol. 
Other 8 patients were diagnosed as AMLM3 using bone marrow morphology, and their karyotypes showed neither $\mathrm{t}(15 ; 17)$ nor PML-RAR $\alpha$ and RARa-PML chimeric signals by FISH. Method for classification of AMLM3 by several categories such as PML-RARa, RARa-PML and rearrangement of RARa gene is shown in Fig. 6. AMLM3 involves APL and non-APL.Non APL AMLM3 can be identified according this classification. AML M3 and M3 variant each have a distinct gene expression type (Haferlach et al., 2005), which will be another reliable method for classification. PML-RARa chimeric gene has a key role in the responsiveness to ATRA as well as in the leukemogenesis of APL (Kohno et al., 2001). Detective range by RARarearrangement, sensitivity to ATRA and FISH using RARa-PML chimeric probe will be helpful for classification in AML M3 including APL and $M 3$ variant. AML M3 having both $P M L-R A R \alpha$ and $R A R \alpha-P M L$ chimeric genes may be consistent to classically identified APL. FISH is more sensitive technique than conventional G-banding chromosome analysis and then analyses of PML-RAR $\alpha$ and RARa-PML by FISH will be helpful to identify a subclass of AMLM3 after conventional Gbanding analysis.

\section{Acknowledgments}

We are indebted to the following people for providing us samples and clinical information; Dr. Dohy $\mathrm{H}$. of Hiroshima Red Cross Hospital, Dr. Kimura A. of Department of Hemato-Oncology, Research Institute for Radiation Biology and Medicine, Hiroshima University and Dr. Arima Y. of Osaka Red Cross Hospital.

\section{References}

1. Amare PK, Baisane $\mathrm{C}$, Nair R, Menon H, Banavali S, Kabre S, Gujrai S and Subramaniam P (2011) Characterization of cryptic rearrangements, deletion, complex variants of PML, RARA in acute promyelocytic leukemia. Ind. J. Hum. Genet. 17(2), 54-58.

2. Asleson $A D$, Morgan $V$, Smith $S$ and Velagaleti GV (2010) Amplification of the RARA gene in acute myeloid leukemia: significant finding or coincidental observation? Cancer Genet. Cytogenet. 202(1), 3337.

3. Bennett JM, Catovsky D, Daniel MT, Flandrin G, Galton DAG, Gralnick HR and Willman CL (2000) Hypergranular promyelocytic leukemia: correlation between morphology and chromosomal translocation including $t(15 ; 17)$ and $t(11 ; 17)$. Leukemia. 14(7), 1197-1200.

4. Bjerrum OW, Philip P, Pressler T and Tygstrup I (1987) Acute promyelocytic leukemia with $t(15 ; 17)$ and t(2;15;17). Cancer Genet. Cytogenet. 28(1), 107111.

5. Brown D, Kogan S, Lagasse E, Weissman I, Alcalay M, Pelicci PG, Atwater S and Bishop JM (1997) A PML/RARa transgene initiates murine acute promyelocytic leukemia. Proc. Natl. Acad. Sci., USA, 94(6), 2551-2536.
6. Brunel V, Lafage-Pochitaloff M, Alealay M, Pelicci PG and Birg F (1996) Variant and masked translocations in acute promyleocytic leukemia. Leuk. Lymphoma. 22(3-4), 221-228.

7. Burnett AK, Grimwade D, Solomon E, Wheatley K and Goldstone AH (1999) Presenting white blood cell count and kinetics of molecular remission predict prognosis in acute promyleocytic leukemia treated with All-Trans Retinoic Acid: Result of the randomized MRC trial. Blood. 93(12), 4131-4143.

8. Calabrese G, Stuppia TMI, Powles R, Swanbury JG, Morizio E, Peila R, Donti E, Fioritoni G and Palka G (1996) Complex chromosome translocations of standard $t(8 ; 21)$ and $t(15 ; 17)$ arise from a two-step mechanism as evidence by fluorescence in situ hybridization analysis. Cancer Genet. Cytogenet. 91(1), 40-45.

9. Dong $S$ and Tweardy DJ (2002) Interactions of STAT5b-RARalpha, a novel acute promyelocytic leukemia fusion protein, with retinoic acid receptor and STAT3 signaling pathways. Blood. 99(8), 26372646.

10. Grignani F and Pelicci PG (1996) Pathogenetic role of the PML-RARafusion protein in acute promyelocytic leukemia. Curr. Top. Microbiol. Immunol. 211, 269-278.

11. Grimwade D, Howe K, Langabeer S, Davies L, Oliver F, Walker H, Swirsky D, Whearley K, Goldstone A, Burnett A and Solomon E (1996) Establishing the presence of the $t(15 ; 17)$ in suspected acute promyelocytic leukemia: Cytogenetic molecular and the PML immunofluorescence assessment of patients entered into the M.R.C.ATRA trial. MRC. Adult Leukemia Working Party. Br. J. Heamtol. 94(3), 557573.

12. Grimwade D, Gorman P, Duprez E, Howe K, Langabeer S, Oliver F, Waker H, Culligan D, Waters J, Pomfret M, Goldstone A, Burnett A, Freemont P, Sheer D and Solomon E (1997) Characterization of cryptic rearrangements and variant translocations in acute promyelocytic leukemia. Blood. 90(12), 48764885.

13. Grimwade D, Biondi A, Mozziconacci MJ, Hagemeijer A, Berger R, Neat M, Howe K, Dastugue N, Jansen J, Radford-Weiss I, Francesco Lo C, Lessard $M$, Hernandez JM, Delabesse E, Head D, Liso V, Sainty $D$, Flandrin G, Solomon E, Birg F and LaffagePochitaloff M (2000) Characterization of acute promyelocytic leukemia cases lacking the classic $t(15 ; 17)$ : results of the European Working Party. Group Français de Cytogénétique Hématologigue, Group de Françaisd'Hematologie Celllarie, UK Cancer Cytogenetics Group and BIOMED 1 Europoian community-concerted action molecular cytogentic diagnosis in haematological malignancies. Blood. 96(4), 1297-1308.

14. Gogineni SK, Shah HO, Lin JH, Garrison M, Alidina A, 
Bayani E and Verma RS (1998) Variant complex translocations involving chromosomes 1, 9, 9, 15 and 17 in acute promyelocytic leukemia without RARa/PML gene fusion rearrangement. Leukemia. 11(4), 514-518.

15. Gu BW, Xiong H, Zhou Y, Chen B, Wang L, Dong S, Yui ZY, Lu LF, Zhong M, Yin HF, Zhu GF, Huang W, Xi Ren S, Gallagher RE, Waxman S, Chen GQ, Wang ZG, Chen Z and Chen SJ (2002) Variant-type $P M L-R A R \alpha$ fusion transcript in acute promyelocytic leukemia: useof a cryptic coding sequence from intron 2 of the RAR $\alpha$ gene and identification of a new clinical subtype resistance to retinoic acid therapy. Proc. Natl. Acad. Sci., USA, 99(11), 7640-7645.

16. Haferlach $T$, Kohlmann A, Schnittger $S$, Dugas $M$, Hideemann W, Kem W and Schoch C (2005) AML M3 and M3 variant each have a distinct gene expression signature but also share patterns different from other genetically defined AML subtypes. Genes Chrom. Cancer. 43(2), 113-127.

17. Haraguchi $K$, Ohno N, Tokunaga M, Tokunaga M, Itoyama Tm Gotoh M, Taniwaki $\mathrm{M}$ and Tubouchi $\mathrm{H}$ (2008) Masked $t(15 ; 17)$ APL with the insertion of PML-RARalpha fusion gene in 4q21. Leuk. Res. 33(11), 1552-1555.

18. Hasen SK, Mays AN, Ottone T, Ledda A, La Nasa G, Gattaneo C, Borlenghi E, Melilo L, Montefusco E, Cervera J, Stephen C, Satchi G, Lennard A, Libura M, BylJA, Osheroff N, Amador S, Felix CA, Voso MT, Sperr WR, Esteve J, Sanz MA, Grimwade D and LCoco $F(2008)$ Molecular analysis of $t(15 ; 17)$ genomic breakpoints in secondary acute promyelocytic leukemia arising after treatment of multiple sclerosis. Blood. 112(8), 3383-3390.

19. Hiorns LR, Min T, Sansbury GJ, Zelent A, Dyer MJS and Catovsky D (1994) Interstitial insertion of retinoic acid receptor-agene in acute promyelocytic leukemia with normal chromosomes 15 and 1. Blood. 83(10), 2946-2951.

20. Hofmann TG and Will H (2003) Body langage; the function of PML nuclear bodies in apoptosis regulation. Cell Death Differ. 10(12), 1290-1299.

21. Huang Y, Hou JK, Chen TT, Zhao -Y, Yan ZW, Zhang J, Yang J, Kogan SC and Chen GQ (2011) PMLRARa enhances constitutive autophagic activity through inhibiting the akt/mTOR pathway. Autophagy. 7(10), 1132-1144.

22. Huntly BJ, Reid AG, Bench AJ, Campbell LJ, Telford N, Shepherd P, Szer J, Prince HM, Kamal NR, Curtis K, Hanson CA and Dewald GW (1996) Acute promyelocytic leukemia with $t(15 ; 16 ; 17 ; 19)$ and unusual fluorescence in situ hybridization pattern with PML, and RARa probes. Cancer Genet. Cytogenet. 92, 54-57.

23. ISCN (2005) An international system for human cytogenetic nomenclature (2005). (ed. L.G. Shaffer and N. Tommerup), Cytogenetics \& Genome Res.,

\section{Karger, Basel.}

24. Kim MJ, Yoon HS, Cho SY, Lee HJ, Suh JT, Lee J, Yoon HJ, Lee WI and Park TS (2010) ider(17)(q10) $t(15 ; 17)$ associated with relapse and poor prognosis in a pediatric patients with acute promyelocytic leukemia. Cancer Genet. Cytogenet. 201(12), 116121.

25. Kohno A, Tsuzuki S, Kasai M, Miyamura K, Emi N, Tanimoto M and Saito H (2001) Acute promyelocytic leukemia with apparently normal karyotype: molecular findings and response to all-trans retinoic acid. Luek. Lymphoma. 42(1-2), 151-161.

26. Kolomietz E, Al-Maghrabi J, Brennan S, Karaskova J, Minkin S, Lipton J and Squire JA (2001) Primary chromosome rearrangements of leukemia are frequently accompanied by extensive submicroscopic deletions and may lead to altered prognosis. Blood. 97(11), 3581-3588.

27. Kumaravel TS, Tanaka K, Kyo T, Dohy $\mathrm{H}$ and Kamada N (2008) Hidden genetic or chromosomal alterations in patients with acute myeloid leukemia showing a cytogenetically normal karyotype. Chrom. Sci. 11, 53-60.

28. Lee GY, Christina S, Tien SL, Ghafar AB, Hwang W, Lim LC and Lim TH (2005) Acute promyelocytic leukemia with PML-RARA fusion on $i(17 q)$ and therapy-related acute myeloid leukemia. Cancer Genet. Cytogenet. 159(2), 129-136.

29. Li YP, Andersen J, Zelent A, Rao S, Paietta E, Tallman MS, Wiernik PH and Gallagher RE (1997) RAR alpha/RAR alpha2-PML $m$ RNA expression in acute promyelocytic leukemia cells: A molecular and laboratory-clinical correlative study. Blood. 90(1), 306-312.

30. Liu H, Tanaka K and Kamada N (2008a) Differential expression of PML in ${ }^{60} \mathrm{Co}$-yrays and $\mathrm{Y}$-IFN-induced apoptosis in B-lymphocytes. Ind. J. Sci. Technol. 1(3), 1-13. http://www.indjst.org.

31. Liu H, Tanaka K and Kamada N (2008b) Increased expression of PML protein in lymphocytes induced by serum from patietns with severe aplastic anemia. Ind. J. Sci. Technol. 1(4), 1-9. http://www.indjst.org.

32. Luatti S, Marzocchi G, Ottaviani E, Baldazzi C, Stacchini M, Gamberini C, Salmi F, Martinelli G, Baccarani M and Testoni N (2008) Acute promyelocytic leukemia with amplification of PMLRAR $\alpha$ rearrangement: Clinical implications. Leuk. Res. 32,1941-1943.

33. Manola K, Karakosta M, Sambani C, Terzoudi G, Pagoni M, Gatsa E and Papaioannou M (2010) Isochromosome $\operatorname{der}(17)(q 10) t(15 ; 17)$ in acute promyleocytic leukemia resulting an additional copy of the RARA-PML fusion gene -report of 4 cases and review of the literature. Acta Haematol. 123(3), 162170.

34. Matsuoka A, Miyamura K, Emi N, Tahara T, Tanimoto M, Naoe T, Ohno R, Kakizuka A, Evans RM and
Research article

(C)Indian Society for Education and Environment (iSee)
"15;17 translocation in leukemia" http://www.indjst.org
K.Tanaka et al. Indian J.Sci.Technol. 
Saito H (1993) Unexpected heterogeneity of PMLRAR alpha fused mRNA detected by nested polymerase chain reaction in acute promyelocytic leukemia. Leukemia. 7(8), 1151-1155.

35. Mistry AR, Felix CA, Whitemarsh RJ, Mason A, Reiter A, Cassinat B, Parry A, Walz C, Wiemels JL, Segal MR, Adés L, Blair IA, Osheroff N, Peniket AJ, LafagePochitaloff M, Cross NC, Chmienne C, Solomon E, Fenaux $P$ and Grimwade D (2005) DNA topoisomerase II in therapy-related acute promyelocytic leukemia. N. Engl. J. Med. 352(15), 1529-1538.

36. Miyazaki K, Kikukawa M, Kikuchi A, Shin K, Iwamoto $T$ and Ohyashiki K (2007) Complex trasnlocations derived stepwise from standard $t(15 ; 17)$ in a patient with variant acute promyelocytic leukemia. Cancer Genet. Cytogenet. 176(2), 127-130.

37. Moon HW, Chang YH, Kim TY, Oh BR, Min HC, Kim BK, Ahn HS, Cho HI and Lee DS (2007) Incidence of submicroscopic deletions varies according to disease entities and chromosomal translocations in hematological malignancies: Investigation by fluorescence in situ hybridization. Cancer Genet. Cytogenet. 175(2), 166-168.

38. Mozziconacci MJ, Liberatore C, Brunel V, Grignani F, Arnoulet C, Francesco PF, Fernandez F, Sainty D, Pelicci PG, Birg F and Lafage-Pochitaloff M (1998) In vitro response to all-trans retinoic acid of acute promyelocytic leukemias with nonreciprocal PML/RARA or RARA/PML fusion genes. Genes Chrom. Cancer. 22(3), 241-250.

39. Occhinorelli M, Santoro F, Pallavicini I, Gruszka A, Moretti S, Bossi D, Viale A, Shing D, Ronzoni S, Muradore I, Soncini M, Pruneri G, Rafaniello P, Viale G, Pelicci PG and Minucci S (2011) The selfassociation coiled -coil domain of PML is sufficient for the oncogenic conversion of the retinoic acid receptor (RAR) alpha. Leukemia. 25(5), 814-820.

40. Park JP, Fairwether RB and Mohandas TK (1997) Isochromosome for derivative $17 q$ in acute promyelocytic leukemia: evidence for two copies of PML-RARA and favorable response to all-transretinoic acid therapy. Gene Chrom. Cancer. 18(2), 151-153.

41. Pearson M and Pelicci PG (2001) PML interaction with p53 and its role in apoptosis and replicative senescence. Oncogene. 20(49), 7250-7256.

42. Redner (2002) Variations on a theme: the alternate translocations in APL. Leukemia. 16(10), 1927-1932.

43. Sakurai $M$, Sasaki $M$, Kamada $N$, Okada $M$, Oshimura M, Ishihara $T$ and Shiraishi $Y$ (1982) A summary of cytogenetic, morphologic, and clinical data on $\mathrm{t}(8 \mathrm{q}-; 21 \mathrm{q}+)$ and $\mathrm{t}(15 \mathrm{q}+; 17 \mathrm{q}-)$ translocation leukemia in Japan. Cancer Genet. Cytogenet. 7(1), 59-65.

44. Stavropoulou C, Ceorgakikos VN, Manola KN, Pagoni M, Garofalaki M, Pantelias GE and Sambani

\section{Vol. 5 No. 9 (Sep. 2012) ISSN: 0974-6846}

C (2008) 5' RARA submicroscopic deletion from new variant translocation involving chromosomes 15,17 , and 18 , in a case of acute promyelocyticleukekemia. Cancer Genet. Cytogenet. 182(1), 50-55.

45. Tanaka K, Hashimoto T, Oguma N, Dohy H and Kamada N (1993) Influence of M-BCR breakpoint sites on duration of chronic phase in 100 patients with chronic myelocytic leukemia. Cancer Genet. Cytogenet. 70(1), 39-47.

46. Tanaka K, Arif M, Eguchi M, Kumaravel TS, Ueda R, Ohno R, Iwato K, Kyo T, Dohy H and Kamada N (1997a) Application of fluorescence in situ hybridization to detect residual leukemic cells with 9;22 and 15;17 translocations. Leukemia. 11(3), 436440.

47. Tanaka K, Arif M, Eguchi M, Kyo T, Dohy $H$ and Kamada N (1997b) Frequent jumping translocations of chromosome segments involving the $A B L$ oncogene alone or in combination with CD3-MLL gene in secondary leukemia. Blood. 89(2), 596-600.

48. Tanaka K and Kamada N (1998) Segmental jumping translocation in leukemia and lymphoma with a highly complex karyotype. Leuk. Lymphoma. 29(5-6), 563575.

49. Tanaka K, Arif M, Eguchi M, Shintani T, Kumaravel TS, Asaoku H, Kyo T, Dohy H and Kamada N (1999) Interphase fluorescence in situ hybridization overcomes pitfalls of G-banding analysis with special reference to underestimation of chromosomal aberration rates. Cancer Genet. Cytogenet. 115(1), 32-38.

50. Tanaka K, Arif M, Kyo. Dohy TH and Kamada N (2000) Transposition of duplicated chromosomal segment involving fused $B C R-A B L$ gene or $A B L$ oncogene alone in chronic myelocytic leukemia and $\mathrm{Ph}$ chromosome-positive acute leukemia with complex karyotypes. Cancer Genet. Cytogenet. 119(1), 8-14.

51. Tanaka K, Minamihisamatsu M, Yagi S, Kyo T, Dohy $\mathrm{H}$ and Kamada N (2001) Two step mechanism for formation of complex 9;22 chromosome translocation in chronic myeloid leukemia, detected by fluorescence in situ hybridization. Exp. Oncol. 23(1), 29-38.

52. Tanaka K, Minamihisamatsu M, Kyo T and Kamada N (2012a) Complex 8;21 translocations formed by two step mechanism and simple 8;21 chromosome translocation without AML1 gene involvement in acute myelocytric leukemia. Ind. J. Sci. Technol. 5(3), 2240-2252.

53. Tanaka K (2012b) Identification of nine chromosomal segments with jumping translocation in 564 human leukemia and lymphomas. Ind. J. Sci. Technol. 5(4), 2473-2486.

54. Tashiro S, Tanaka K, Asou H, Kyo T, Dohy H, Ssuzuki K and Kamada N (1993) Detection of $\mathrm{PML} /$ Retinoic acid receptor a gene rearrangements
Research article

(C)Indian Society for Education and Environment (iSee)
"15;17 translocation in leukemia" http://www.indjst.org
K.Tanaka et al. Indian J.Sci.Technol. 
by polymerase chain reaction using genomic DNA in patients with acute promyelocytic leukemia. Jpn. Cancer Res. 84(2), 110-113.

55. The 4th International Workshop on Chromosomes in Leukemia (1984) Chromosomes in acute promyleocytic leukemia. Cancer Genet. Cytogenet. 11, 288-293.

56. Turner P, Grace C, Nacheva EP and Green AR (2001) Deletions of the derivative chromosome 9 occur at the time of the Philadelphia translocation and provide a powerful and independent prognositic indicator in chronic myeloid leukemia. Blood. 98(6), 1732-1738.

57. Viguié Aboura A, Ramond S, Buscary D, Bausdard M, Chmienne C and Marie JP (2000) Submicroscopic insertion of RAR alpha gene into chromosome 15 in two cases promyelocytic leukemia. Cancer Genet. Cytogenet. 119(2), 162-164.

58. Walter MJ, Ries RE, Armstrong JR, Park JS, Mardis ERS and Ley TJ (2007) Expression ofa bcr-1 isoform of RARalpha-PML does not affect the penetrance of acute promyelocytic leukemia or the acquisition of an interstitial deletion on mouse chromosome 2. Blood. 109(3), 1237-1240.

59. Walz C, Grimwade D, Sausselle S, Lengfelder E, Haferlach C, Schnittger S, Lafage-Pochitaloff $M$, Hochhaus A, Cross CP and Reiter A (2010) Atypical mRNA fusions in PML-RARA positive, RARA-PML negative acute promyelocytic leukemia. Genes Chrom. Cancer. 49(5), 471-479.

60. Wells RA, Catzavelos C and Kamel-Reid S (1997) Fusion of retinoic acid receptor a to NuMA, the nuclear mitotic apparatus protein, by a variant translocation in acute promyelocytic leukemia. Nature Genet. 17(1), 109-113.

61. WHO Classification of Tumours 2007 (2008) WHO Classification of Tumours of Heamatopoietic and Lymphoid Tissues, Edited by S.H. Swerdlow, E. Campo, N. Harris, E.S. Jaffe, S.A. H. Pileri, , J. Stein, J. Thiele and J.W. Vardiman. Intl. Agency Res. Cancer, Lyon.

62. Yamamoto K, Hamaguchi H, Nagata K, Kobayashi M, Takahashi M, Takashima T and Taniwaki M (1998) A new complex translocation $\mathrm{t}(15 ; 20 ; 17)(\mathrm{q} 22 ; \mathrm{p} 13 ; \mathrm{q} 21)$ in acute promyelocytic leukemia. Cancer Genet. Cytogenet. 101(2), 89-94.

63. Yang S, Kuo C, Bisi JE and Kim MK (2002) PMLdependent apoptosis after DNA damage is regulated by the checkpoint kinase hCds1/Chk2. Nature Cell Biol. 4(11), 865-870. 